\title{
PERSONALIZATION OF SPACE IN PRIVATE AND PUBLIC SETTING WITHIN VERTICAL HOUSING AS SUSTAINABLE LIVING
}

\author{
Susy Budi Astuti ${ }^{1}$, Purwanita Setijanti ${ }^{2}$, Ispurwono Soemarno ${ }^{3}$ \\ ${ }^{12.3}$ Department of Architecture, Institute of Technology Sepuluh Nopember \\ Jl. Arief Rahman Hakim, Surabaya, INDONESIA \\ Emails: 1susy@interior.its.ac.id. 2psetijanti@arch.its.ac.id, ${ }^{3 i s p} 4251 @$ yahoo.com
}

\begin{abstract}
Personalization is an individual or group"s ownership of a place or object, initially as physical and non-physical. The quality of housing which is influenenced by the social environment, economy, culture, defines the life of the inhabitant. Welfare, security, assuredness of infrastructure, housing quality, environment quality and the human resources are the elementsthat should be sustainable living. Housing as a physical function, is a shelter that is designed with physical building quality.While housing as a social function is reviewed based on the inhabitant's behavior (both individually and socially) withits enviroment. The process of personalization aims to meet the needs and achievements thatsuits the user group's character to generate sustainable living. Personalization in personal/private territory includes individual or a group's participation, whereas in communal territory the participants are constantly changing. The phenomenon of ownership and involvement in different settings, is an interesting subject to obtain a deeper understanding of, on the different concepts of personalization. This research aims to formulate personalization based on ownership and involvement of vertical apartment residence in private and public setting. Several researches state that vertical apartment residences tend to pay less attention to social/public factors, despite the presence of a public space with shared ownership. This research is conducted with a qualitative method which is initiated with literature review on the realm of study of Environment Behavior Studies along with questionnaire and observation to represent results of field data. Within this research, the results of discussion regarding personalization of space behavior is a study concept of the sustainability living of community in apartment residence that suits the user group"s character, which is in private and public setting. So expect this study may be considered for housing planning policy in urban apartments which not only the physical factors of structural but also character of its occupants.
\end{abstract}

Keywords: Behavior; personalization; sustainable living.

\section{INTRODUCTION}

Altman (1976) elaborated that environment behavior studies consists of 3 components, which are environment-behavior phenomena, user group and settings. Behavior phenomena to the environment will vary, due to the difference of meaning, symbol and also the way human make use of the environment as self-representation. For example is privacy, is a personal behavior phenomena that is related to the individual behavior pattern, rules and the social system within the environment. The difference within the user group will bring out different needs and activity pattern, while setting according to Altman is the scale of the environment in which the activity takes place.

According to Altman (1976), personalization is an individual or group es ownership of a place or object, through concrete (physical) or symbolic (nonphysical) self-initial signs. According to Brower (1976) the physical is noticeable by occupancy, and the non-physical is marked by attachment to the place. Occupancy is marked by object placement, for instance wall partition, fence, vase, nameplate, fish pond, etc. Whereas attachment is observed by the user"s attachment to a place or object, for example the frequent visit to a park due to its easiness of reach, the relaxed manner of sitting in a lobby because of feeling familiar in that situation, etc. Saruwono (2007) stated that personalization can be reviewed as positive (phenomenon) and negative (problem), because personalization is a process that adapts the needs of a certain individual or group.

Personalization as occupancy. Occupancy is a temporary ownership, because it is also a part of ownership to others. So that is a form of behavior of effort in order to own territorial ownership. Altman (1980) stated as a territorial claim, territorial expression in relation with residence. There are 4 types of occupancy, personal, community, public and free. Personal Occupancy is done by an individual or a group that has a strong relation due to kinship, marriage, family or high loyalty. The ownership is controlled and permission is limited to others, because it is the greatest freedom territory of its occupant. The personal ownership sign shows its occupantes identity, it is private. Community Occupancy, is done by a group/community in which the participants are 
constantly changeable through a determined selection process mechanism. Sign or community claim of a place is established through sharing physical setting and value/belief system.This means that ownership signs of community is in the practice of activity and symbols of the participants ie interest/importance. So there are 3 basic elements in understanding of occupancy, i.e. sustainability of space usage, the person who make use of the space and display/sign of space.

Personalization as preference. The personalizetion is suited with the needs and habits of each family member which reflects theirown personality and also suited with the environment surrounding them. Moreover, personalization at the side parts ofthe house are more to add esthetics to the house (garden, living room expansion, terrace). Sazally (2012) explained that house changes and renovation occurs due to individual preference aspect or familyneeds. The renovation mostly occurs on the front side of the house, than the back or the sides.

Personalization as experiences. Living in a vertical housing is a new culture for Indonesian people, so that some of the time activities that areexecuted in horizontal housing are carried to the new housing environment whichis the vertical housing. The density ofhousing unit at a vertical housing contributes to small space for the user, even just in talking or fulfill the needs oflistening to a high volume music. So that speaking or using loud audio system will disturb the unit neighbors or even theusers overall. Here, the users are to adapt themselves to not to disturb the neighborhood. Kurokawa (1994) emphazises the importance of having an element and intermediation space within the housingenvironment. Intermediation space or semi-public space can be very meaningful to the user. The physical housing environment needs to be built upon culture, faith and the user's experience (Ismail, 2012). Cho"s (2007) research stating that to create aculture based vertical housing concept, emphasizes on the need of community space for togetherness. Community spacea social environment aspect is used by sharing, which the uses are defined by the management. Raman (2010) statedthat social relation within vertical housing user are very low, because social interaction mostly occur in the same floorlevel users.

Public setting is necessary for landed housing, because people tend to move horizontally. Conversely, how the character of the activity in public and privacy space in vertical housing. Vertical housing in these reasearch is apartment. The ownership of public space of apartment is not separated from the individual unit/unit privacy. The activity that occurs in the public space is the continuity and closely linked to activity in the unit privacy. So, how the character of privacy and public behavior of occupants in the apartment.These research purposed to formulated the sustainable living in apartment through personalisation of space in private and public setting. Because the sustainable living does not only depend on the private setting, but more on the physical and social environment in public setting.

\section{RESEARCH METHODS}

Ideally, behavioral research is observed continuously and repeatedly in a certain length of time. A consequence of using the naturalistic qualitative method, the researcher"s position is as an instrument in conducting the observation. Bogdan (1982 in Moleong, 1999) stated that research observation is a form of social interaction that requires time between the researcher and the subject in the observed subject environment. Data in the form are constructed systematically, continuously. However within this research data will be obtained with questionnaire technique. The aim is to obtain a common private and public behavior concept. This is a prelimenary step to the next research.

Object Selection. Apartment vertical residence is rapidly developing in big cities such as Jakarta, Surabaya, and other big cities in Indonesia. In order to be more focused and look for more depth in character, so another city with a more specific aspects is chosen. Surabaya is seen to be more specific, because it is an industrial, trading and maritime city. Surabaya is also known as a city of education. The rapid growth and development of apartments in Surabaya one of which is due to the number of higher education institutions especially in the eastern area of Surabaya. Apartment is not only seen as an alternative residence, it has also become a part of lifestyle. The selected apartment is not integrated with another public function (i.e. mall, hotels, office, etc). Because this character can affect the spesific behavior of the residents.

Respondent Selection. To obtain external validation, the respondent"s data and activities are executed naturally without intervention from the researcher, to get general results (Holahan, 1980). The proposed respondents are residents of some apartments in Surabaya. The types of residents are those who are with family/married and single, so the respondents are spread through a few types of unit apartment, studio until one - three bedrooms type.

\section{RESULTS AND DISCUSSION}

This research conducted on 68 respondents. The respondents socio-demographic character shows that they are between the age of 20-40, married/single. They occupy the studio type or 1-3 bedrooms (Table 
1). So that personalization of space character in private setting in the apartment unit is represented in all types of unit. The length of inhabit are between 2-5 years, by tenant or owner. These aspects can represent the sense of belonging towards a room, both physically (occupancy) or non-physically (attachment).

Tabel 1. Respondents Data

\begin{tabular}{cllc}
\hline No & \multicolumn{1}{c}{ Variables } & \multicolumn{1}{c}{ Attribute } & Prosentace \\
\hline 1 & Ages & $20-40$ age & $94 \%$ \\
2 & Sex & female & $74 \%$ \\
3 & Job/Profession & Student and & $63 \%$ \\
& & entrepreneuer & \\
4 & The ownership status & tenant & $53 \%$ \\
& of unit & owner & $47 \%$ \\
5 & Unit Type & $1-3$ Bedrooms & $59 \%$ \\
6 & Conditions & Own & $87 \%$ \\
& & with family & $13 \%$ \\
7 & Children age & Under 7 years & $53 \%$ \\
8 & Status & Married & $23 \%$ \\
& & single & $77 \%$ \\
9 & Stay & $2-5$ years & $66 \%$ \\
10 & Experiences of living & Never & $47 \%$ \\
& in apartment & ever & $53 \%$ \\
11 & Culture backgrond & Java & $67 \%$ \\
& & others & $33 \%$ \\
\hline
\end{tabular}

Source: Questionnaire (2016)

\section{Personalization of Space in Private Setting}

There are difference occupancy in a private setting, for those who are married the kitchen functions a cooking area, so the room is used as it is intended. For those who are single, the kitchen is a part of the living/bedroom. The kitchen is not used as it is intended. A Private setting in apartment unit spreads to corridors, which is when the door is opened to watch over the children playing in the corridor (Figure 1). The corridor, for those who are married (especially with children) is a public/social space (to look over children, chat, interact), whereas for those who are single, it is perceived as a private space because of their individual activity. Attachment to private setting in an apartment unit is by the sense of responsibility to take care of the unit independently, making use of the private space as personal so that it should be kept calm, safe and comfortable. The unit should be in a locked condition whenever the user is out. The following table 2 shows the occupancy of a private setting in an apartment unit.

Occupancy personal in private setting occurs within the apartment unit (privacy intimacy) with the power of control by each individual or group who has

Tabel 2. Personalization of Space in Private Setting

\begin{tabular}{|c|c|c|c|c|c|}
\hline \multicolumn{6}{|c|}{ Personalization space in the unit apartment } \\
\hline No & Behavior & & Family & & single \\
\hline 1 & Place of babbysitting & Playground $100 \%$ & High social interaction & & \\
\hline 2 & $\begin{array}{l}\text { Time of babysitting } \\
\text { outside the unit }\end{array}$ & $\begin{array}{l}\text { On Holiday, there are } \\
\text { no pepole }\end{array}$ & Privasi $=$ time for activity & & \\
\hline 3 & cooking & seldom & The kitchen is rarely used & seldom & The kitchen is rarely used \\
\hline 4 & $\begin{array}{l}\text { Playground in room } \\
\text { unit }\end{array}$ & $\begin{array}{l}\text { bedroom and living } \\
\text { room }\end{array}$ & All is private space for children & & \\
\hline 5 & $\begin{array}{l}\text { Kitchen as a apart of } \\
\text { thelivingroom }\end{array}$ & no & $\begin{array}{l}\text { All space is usage as their } \\
\text { function }\end{array}$ & yes & All room as livingroom \\
\hline 6 & $\begin{array}{l}\text { Maintaning the room } \\
\text { unit }\end{array}$ & independent & $\begin{array}{l}\text { High privacy related to } \\
\text { ownership }\end{array}$ & yes & $\begin{array}{l}\text { High privacy equal with } \\
\text { the ownership }\end{array}$ \\
\hline 7 & spare time activity & $\begin{array}{l}\text { Go outside, shopping, } \\
\text { swimming, etc }\end{array}$ & Privacy occurs to share place & Watching tv, sleep & The unit as privacy \\
\hline 8 & $\begin{array}{l}\text { Identity on the room } \\
\text { unit door }\end{array}$ & $\begin{array}{l}\text { none } 63 \% \\
\text { interested } 37 \%\end{array}$ & $\begin{array}{l}68 \% \text { never stay at apartment, } \\
\text { they want but it is restricted }\end{array}$ & $\begin{array}{l}\text { None } 85 \% \\
\text { interested } 9 \% \\
\text { present } 6 \%\end{array}$ & More Activity in outside \\
\hline 9 & Corridor usage & Social space & interaction & Private space & Not disturb \\
\hline 10 & $\begin{array}{l}\text { Open door the room } \\
\text { unit }\end{array}$ & agree & $\begin{array}{l}\text { Corridor as a part of unit, } \\
\text { expancy privacy }\end{array}$ & disagree & Keep privacy \\
\hline 11 & $\begin{array}{l}\text { The sense of belonging } \\
\text { of corridor }\end{array}$ & yes & Corridor as a expansion of & yes & $\begin{array}{l}\text { Corridor as a intermediary } \\
\text { space }\end{array}$ \\
\hline 12 & Guest in the room unit & yes & $\begin{array}{l}\text { The room unit is the public } \\
\text { space }\end{array}$ & yes & $\begin{array}{l}\text { The room unit is the public } \\
\text { space }\end{array}$ \\
\hline 13 & A place to take Guests & lobby & $\begin{array}{l}\text { Lobby as a public space that } \\
\text { privacy }\end{array}$ & lobby & $\begin{array}{l}\text { Lobby as a public space } \\
\text { that privacy }\end{array}$ \\
\hline
\end{tabular}

Source: Questionnaire (2016) 
attachment (friend /family). Ownership sign physical/ in private unit suits the intended occupants. 1-3 bedroom unit type is occupied by singles with roommates or family. In private setting is more personal for single occupants, whereas for those married/with family private setting spreads to community occupancy in public setting. Physical ownership sign at apartment unit as personal is not marked with identity that is permanent. There are no or not seen any occupant's identity on the corridor walls, except signs that are provided by the apartment's management (number on door or corridor).Occupant's attachment to private setting in the apartment unit is due to the need of high privacy.
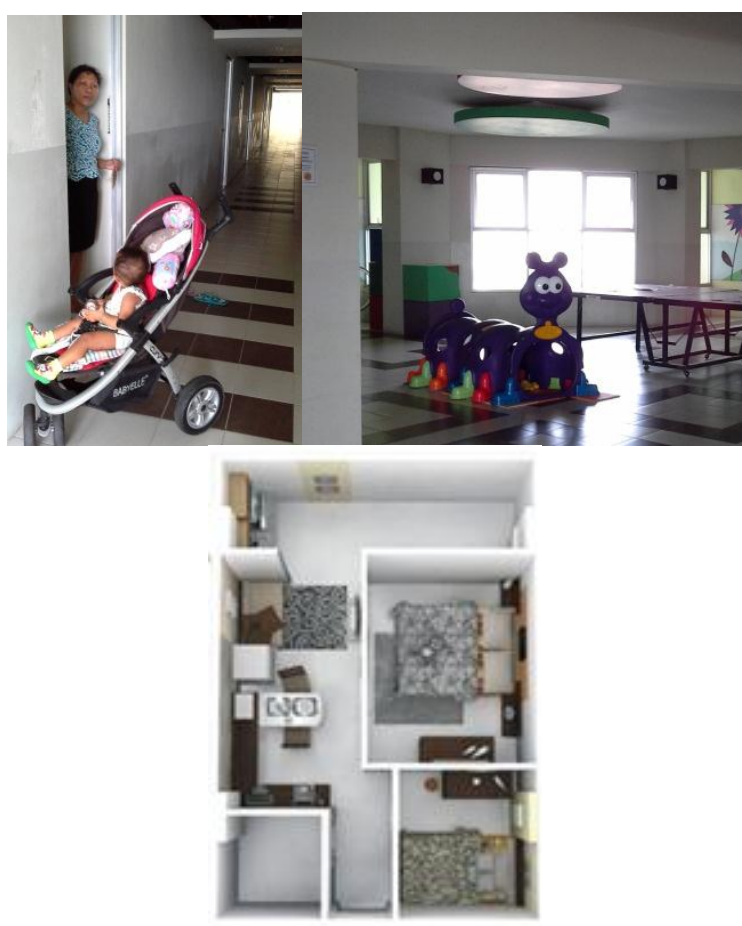

Fig. 1. Occupancy Behavior in the Unit Apartment (researcher documentation, 2016)

\section{Personalisazation of Space in Public Setting:}

Corridor as a public setting is facility of access to units or other public facilities (lift, playground, swimming pool, etc.). Corridor as Public setting because it can be accessed by all the occupants (of the same floor) or by visitors with security pass. Corridor becomes a meeting point of the private and the public setting. Due to the constant change in residents, the personalization in corridor are much more of a nonverbal behavior. Social interaction in corridor as a public setting because of the shared sense of belonging, however without or not necessarily acquainted.Visual contact, smiling and greeting is temporary as they pass each other while doing their own activities in the morning, afternoon and evening (Figure 2). Lobby as a public setting is a facility of meeting point to the residents with visitors. The lobby is seen through the activity of sitting on a chair and talk with other occupants or visitor. Lobby can be a private aspectes extension to the public setting (waiting for guest, checking the mailbox, catering, laundry). Those things occur because visitors are prohibited from accessing the apartment units (Figure 3). Table 3 shows the level of occupancyin public setting.

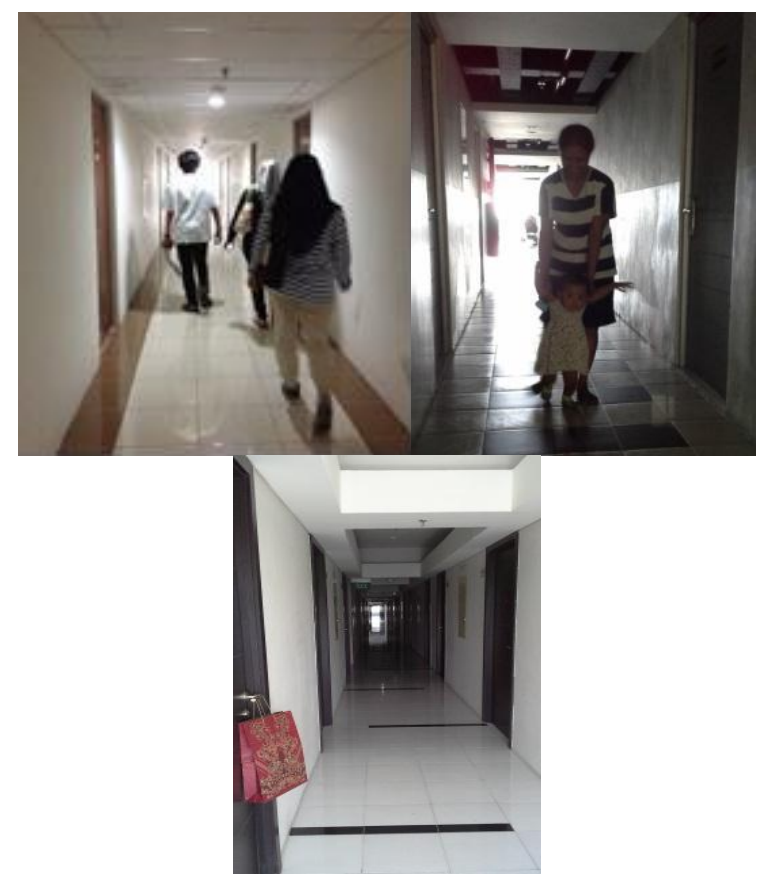

Fig. 2. Occupancy behavior in corridor (researcher documentation, 2016)

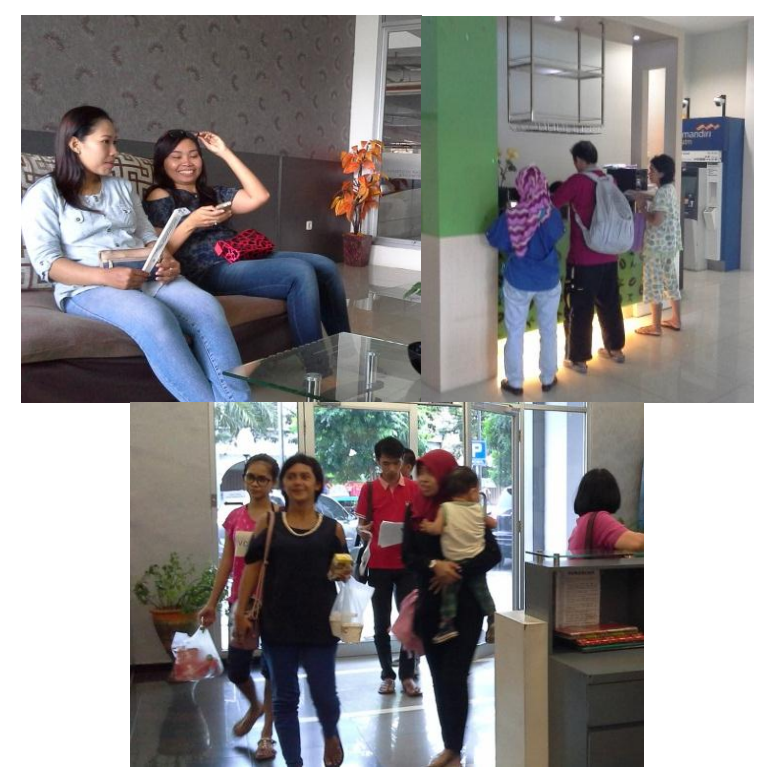

Fig. 3. OccupancyBehavior in Lobby (researcher documentation, 2016) 
Tabel 3. Personalization of Space in Public Setting

\begin{tabular}{|c|c|c|c|}
\hline \multicolumn{4}{|c|}{ Personalization of Space in Public Setting } \\
\hline No & Behavior & Questionnaire & Occupancy and Attachment \\
\hline \multirow[t]{2}{*}{1} & Corridor's function & Public 39\% & Private meets Public \\
\hline & & Privat $37 \%$ & \\
\hline \multirow[t]{3}{*}{2} & Level of acquaintance between & Just know 39\% & occupant of a changing \\
\hline & occupants on the the floor & Not acquainted $34 \%$ & \\
\hline & & Know $27 \%$ & \\
\hline \multirow[t]{3}{*}{3} & Meeting other occupants in the & Smile $56 \%$ & Non verbal behaviour \\
\hline & corridor & Greet $15 \%$ & \\
\hline & & Silent $29 \%$ & \\
\hline \multirow[t]{2}{*}{4} & Making use of corridor to call & No $56 \%$ & Verbal behavior for theprivacy needs \\
\hline & & Sometimes $44 \%$ & \\
\hline \multirow[t]{3}{*}{5} & Opening the unit"s door as & Yes, to watch over them $59 \%$ & Privacy of moving to a public space \\
\hline & children are playing in the & Yes, it is a habit $7 \%$ & Open social interaction \\
\hline & corridor & No, not safe $24 \%$ & \\
\hline \multirow[t]{2}{*}{6} & Should there be a corridor for & Yes, there should $73 \%$ & Private meets public \\
\hline & the children? & & Social interaction with spacial \\
\hline \multirow[t]{3}{*}{7} & When there is garbage in the & Take and put it in the garbage $44 \%$ & Abandon it \\
\hline & lobby & Marginalized $32 \%$ & Private meets public \\
\hline & & Allowed $24 \%$ & $\begin{array}{l}\text { Spatial and non-spatial ownership. } \\
\text { (awareness of hygiene) }\end{array}$ \\
\hline \multirow[t]{2}{*}{8} & $\begin{array}{l}\text { Position of walking circulation } \\
\text { in the corridor }\end{array}$ & $\begin{array}{l}\text { In the middle, on the sides if coming across another } \\
81 \%\end{array}$ & High spatial ownership, private/individual \\
\hline & & Always in the middle $19 \%$ & \\
\hline \multirow[t]{4}{*}{9} & Freedom to perform activity in & Yes, when there are no/not many people $68 \%$ & Yes, when there are no/not many people \\
\hline & the corridor & No $32 \%$ & $59 \%$ \\
\hline & Private meets public & & No $32 \%$ \\
\hline & High ownership but temporary & & \\
\hline \multirow[t]{3}{*}{10} & Is talking loudly in the corridor & Yes, Especially in the evening $49 \%$ & Corridor as public space \\
\hline & disturbing? & Yes, when coming across other occupants $42 \%$ & Nonverbal personalization (audio) \\
\hline & & No problem $9 \%$ & High ownership but temporary \\
\hline \multirow[t]{2}{*}{11} & Manner of walking in the & Walk relaxedly $93 \%$ & familiar area, privacy \\
\hline & corridor & Walk fast $7 \%$ & \\
\hline \multirow[t]{2}{*}{12} & Other behavioral gesture in the & Chatting/calling $68 \%$ & Verbal behavior, privacy \\
\hline & corridor & Smoking $32 \%$ & \\
\hline \multirow[t]{4}{*}{13} & Activity time in the corridor & Morning and between afternoon and evening $49 \%$ & Spatial behavior in corridor is related to \\
\hline & & Evening $36 \%$ & time morning, afternoon and evening: \\
\hline & & Afternoon $15 \%$ & sharing spatial corridor and social \\
\hline & & & $\begin{array}{l}\text { interaction daytime: Private activities (shop, } \\
\text { baby sitting, }\end{array}$ \\
\hline \multirow[t]{3}{*}{14} & Signage on unit"s door & Not interested $54 \%$ & Corridor as public setting, privacy should \\
\hline & & Interested but prohibited $25 \%$ & be maintained \\
\hline & & None $21 \%$ & \\
\hline \multirow[t]{2}{*}{15} & Feeling familiar with the & Yes $64 \%$ & Private setting \\
\hline & corridor in front of the unit. & No $36 \%$ & \\
\hline 16 & The need to change clothes & No need $80 \%$ & Attachment on shared ownership, feels \\
\hline & when going out to the lobby & Yes $20 \%$ & private \\
\hline 17 & The freedom in the lobby & Yes, when not crowded $61 \%$ & Private, non Verbal \\
\hline & & No, when crowded $39 \%$ & \\
\hline 18 & Coming across other occupants & Smile $52 \%$ & Visual behavior \\
\hline & in the lobby & Nothing $17 \%$ & Non verbal \\
\hline & & Silent $31 \%$ & \\
\hline 19 & Preferred position sitting in the & In front of other occupants and nonverbal contact $46^{\circ}$ & Non verbal and visual behavior \\
\hline & lobby & Next to other occupants, nonverbal contact $37 \%$ & \\
\hline & & In front of / the next, verbal contact $17 \%$ & \\
\hline 20 & Familiarity with the lobby & Yes, greet often $53 \%$ & Verbal behavior, visual \\
\hline & officer & Just Know $42 \%$ & \\
\hline & & Not know $5 \%$ & \\
\hline$\underline{21}$ & Making use of sport facilities in & Yes, not routinely $51 \%$ & High ownership \\
\hline & the apartment & Yes, routine $30 \%$ & Community and refreshing \\
\hline & & Yes, for refreshing $19 \%$ & \\
\hline 22 & $\begin{array}{l}\text { Changing clothes location for } \\
\text { sport }\end{array}$ & $\begin{array}{l}\text { unit privacy } 61 \% \\
\text { toilet in sport area } 39 \%\end{array}$ & Privacy from unit to sport facility (public) \\
\hline 23 & Duration of sport & $30-60$ minutes $66 \%$ & High ownership \\
\hline & & $>60$ minutes $34 \%$ & \\
\hline 24 & Making use of laundry service, & Yes $90 \%$ & Community space \\
\hline & shop and café of the apartment & No $10 \%$ & \\
\hline
\end{tabular}


Tabel 4. Occupancy in Public Setting

\begin{tabular}{lrlll}
\hline \multicolumn{1}{c}{ Time Sharing spasial } & $\%$ & \multicolumn{1}{c}{ Behavior } & \multicolumn{1}{c}{ Activity } \\
\hline $\begin{array}{l}\text { Morning } \\
\text { afternoon }\end{array}$ & $49 \%$ & Public behavior & - Go to school/campus or work & Social interaction with verbal, non \\
evening & & Social interaction & - Greet, smile & verbal and visual \\
daytime & $36 \%$ & & - Short time & Social interaction for privacy \\
& $15 \%$ & Privacy behavior & - shopping & \\
& & & - parenting & \\
& & & - Refreshing \\
& & & - A lot of time
\end{tabular}

Tabel 5. Physical and non Physical Sharing in Public Setting

\begin{tabular}{|c|c|c|c|}
\hline \multicolumn{2}{|c|}{ Sharing physical/spasial } & \multicolumn{2}{|c|}{ Sharing non physical/non spasial } \\
\hline Attached Variabel & Free variable & Attached variable & Free variable \\
\hline $\begin{array}{l}\text { Proxemics (physical distance }> \\
\text { between human) }\end{array}$ & $\begin{array}{l}\text { Keeping privacy space in } \\
\text { corridor and lobby } \\
>\text { Dynamic personal space, } \\
\text { which is from the personal } \\
\text { to public area }\end{array}$ & $\begin{array}{l}\text { Behavioral adjustment } \\
\text { with the public }\end{array}$ & $\begin{array}{l}\text { > Non verbal behavior: Smiling, } \\
\text { nodding } \\
>\text { Visual behavior: Eye contact, } \\
\text { staring } \\
>\text { Audio: Walkingrelaxed, voice } \\
\text { volume. }\end{array}$ \\
\hline $\begin{array}{l}\text { Privacy needs in public } \\
\text { setting }\end{array}$ & $\begin{array}{l}\text { Privacy facility in public } \\
\text { setting.or example: } \\
\text { Laundry, food/ catering, } \\
\text { mail, ATM }\end{array}$ & $\begin{array}{l}>\text { Safety } \\
>\text { Comfort }\end{array}$ & $\begin{array}{l}\text { > Access cards for occupants, so } \\
\text { there is clarity in access and } \\
\text { boundary in private and public } \\
\text { setting. } \\
>\text { The susitability of facility use }\end{array}$ \\
\hline
\end{tabular}

Personalization in public setting starts from the lobby facility to corridor. On a wider scale, lobby and corridor could mean as private setting because it is part of apartment occupantes facility, however looking from the perspective of the internal circumstance, lobby and corridor is place where occupants and visitors meet or even between occupants. Therefor lobby and corridor is as a public setting to the internal of the apartment environment. As a meeting point of occupants and visitors, so based on table 3 above, lobby and corridor is a place for physical/spatial and non physical/spatial sharing. Physical sharing spatially is linked to time variable, in this case the occupants of apartment tend to meet to socially interact in the morning, afternoon and evening. That is as they are going to work/campus and coming home from work/campus. Due to the varied characters of occupants within the apartment's public setting every day, spatial sharing organizes the physical closure between occupants (Table 4). When coming across each other in the corridor, occupants will take the position on the side, when walking alongside theytend to not overtake. That also counts in spatial sharing in lobby, they tend to take closer positions when sitting in the lobby. But the importance of privacy is facilitated with lobby. Meaning that there is a place to entrust laundry, catering, mail, etc. The need of privacy in public setting becomes a facility for occupants to interact each other and with the officers. The togetherness because of the importance of privacy in public setting becomes a continuity value to the occupants.
Non-spatial sharing in public setting is nonverbal interaction behavior (smiling, nodding), visual (staring at each other without greeting because not well acquainted but knows that they are occupants as well) and audio (not talking loudly/shouting carelessly, using appropriate language). Physical/nonphysical sharing that occur in public setting as occupancy of community (Table 5).

\section{CONCLUSIONS}

Personalization space in a private setting related to the character of occupants. Corridors is also a privacy setting for families with children. Not so for the single, that the privacy setting is just in unit apartments.Personalization space in a public setting is a sharing spatial and non-spatial. Sharing Spatial as social interaction between occupants, occupants with visitors or officer, realized by using the space together. Sharing non-spatial, is a sharing that is characterized by the presence of an access card. The existence of the access card sign gives a sense of security and comfort for occupants.

\section{REFERENCES}

Altman, I. (1976). The Environment and Social Behavior, Monterey, CA, Wadsworth.

Altman, I. \& Chemers, M. (1980). Culture and Environment, Monterey, California. 
Altman, I., Rapoport, A. \& Wohlwill (1980). Human Behavior and Environment: Advances in Theory and Research, Plenary Press, New York.

Brower, S.N. (1976). Territory in Urban Settings, dalam Human Behavior and Environment, Plenary Press, New York.

Francescato, G., Weidemann, S. \& Anderson, J. R. (1987). "Residential satisfaction: Its uses and limitations in housing research, in Housing and Neighbourhoods: Theoretical and Empirical Contributions. Vliet, W. V., Choldin, H., Michelson, W. and Popenoe, D (eds.). Westport, Connecticut: Greenwood Press.

Holahan, J.C. (1980). Environmental Psychology, Random House, New York.

Kurokawa, K. (1994). The Philosophy of Symbiosis: Academy Editions, Limited.
Lang, J. \& Moleski, W. (2010). Functionalism Revisited, Ashgate Publishing Limited, England. Moleong, J. L. (1999). Metodologi Penelitian Kualitatif, PT. Remaja Rosdakarya, Bandung.

Onibokun, A.G. (1974). "Evaluating Consumers' Satisfaction with Housing: An Application of a System Approach", Journal of American Institute of Planners, 40(3), pp. 189-200.

Sazally et al. (2012)."Personalization of Terrace Houses in Section 7, Shah Alam, Selangor", Procedia-Socialand Behavioral Sciences, 49, pp. 319-327.

Saruwono, M. (2007). An Analysis of Plans of Modified Houses in an Urbanised Housing Area of Malaysia, the University of Sheffield.

Scanell, L. \& Giffort, R. (2010). "Defining Place Attachment: A Tripartite Organizing Framework", Journal of Environmental Ps. 